www.jmscr.igmpublication.org

Impact Factor (SJIF): 6.379

Index Copernicus Value: 71.58

ISSN (e)-2347-176x ISSN (p) 2455-0450

crossref DOI: _https://dx.doi.org/10.18535/jmscr/v6i4.138

Journal Of Medical Science And Clinical Research

\title{
The Effect of Counseling on Knowledge, Attitude, and Practice of Conducting HIV/AIDS Examination among Commercial Sex Workers
}

\author{
Authors \\ Suparmi $^{1^{*}}$, Ulfa Musdalifah ${ }^{2}$, Sumiyati $^{3}$, Puji Hastuti $^{4}$, Anita Widiastuti $^{5}$ \\ 1,2,3,4,5 Poltekkes Kemenkes Semarang, Indonesia \\ *Corresponding Author \\ Suparmi \\ Email: parmiadi@ymail.com
}

\begin{abstract}
Background: HIV (Human Immune-deficiency virus) is the virus that causes AIDS (Acquired Immune Deficiency Syndrome). AIDS is a symptom of diminished capacity defense caused by immune deficiency caused by HIV. In Central Java, Indonesia, the prevalence of HIVIAIDS cases is high enough in 2014 ( more than 500 HIV cases and 400 AIDS cases where the second most abundant group is found in Banyumas Regency due to the availability of prostitution complex in this area.

Objective: The study aimed to determine the effect of education on knowledge, attitude, and practice of commercial sex workers to conduct HIV/AIDS test.

Methods: This is a quasi-experimental research design using one group pretest and posttest. The population and the sample were 92 respondents applying total sampling using a questionnaire and checklist. Data were analyzed using Wilcoxon and Nemar test.

Results: There are differences in knowledge, attitudes, and practices among commercial sex workers to conduct HIV / AIDS test before and after counseling.

Conclusion: Counseling is essential to be provided to the prostitutes in the order they know if they have HIV/AIDS that they take preemptive action before the disease spread further.

Keywords: HIV/AIDS, counseling, knowledge, attitudes, practices, prostitutes.
\end{abstract}

\section{Introduction}

In Indonesia, the cumulative number of new AIDS cases from April 1987 to December 2010 amounted to 24, 131 cases, with the death of 4,593 people. AIDS affects 32 provinces in Indonesia where five regions with a cumulative incidence of AIDS cases and deaths the highest are Jakarta, East Java, West Java, Papua, and Bali (Kemenkes, 2015).

In Banyumas, one of the regencies in Central
Java Province, the number of cases in 2013 is amounted to 430 cases, an increase in 2014 as many as 453 cases (Dinkes Banyumas, 2015) and the figures tend to increase in the coming year.

Some risk factors for the spread of HIV / AIDS in Indonesia occurred because of risky sexual relations, namely the commercial sex workers (CSW) and their clients (male, female sex buyers) and bisexuals. The CSW has a high risk 
to the dangers of HIV / AIDS that they should have the awareness to avoid this disease as well as to have the knowledge and awareness of the importance of prevention of sexually transmitted infections and HIV either by routinely testing for HIV/AIDS voluntarily.

From the above background, the researcher is interested in researching the effect of education about HIV / AIDS (Human Immune-Deficiency Virus/Acquired Immune Deficiency Syndrome) on knowledge, attitude and practice to implement HIV/AIDS test among the prostitutes.

\section{Material and Methods}

This study is a quasi-experimental using design of one group pre and post-test. The group carried out the pre-test before being given counseling on HIV /AIDS later on. In this study, the independent variable is education about HIV / AIDS, while the dependent variable is the knowledge, attitudes, and behaviors of the whores to implement HIV / AIDS test. Results of this study were to compare the results of the knowledge, attitudes, and behavior between pre-test and post-test after the intervention given by samples of 92 respondents. he collection of data is to use questioner and checklist. The data analysis was conducted by examining normality of data by using Kolmogorov-Smirnov test and when obtaining $p$ value $=0.000 \quad(<0.05)$ meaning the data distribution is not normal. The different analysis of knowledge and attitude variables applied the Wilcoxon test, and the various behavioral variables of HIV test used Mc Nemar test due to the scale of nominal data (Arikunto, 2010).

\section{Results}

Characteristics of respondents are teenagers aged $15-25$ years $(65.22 \%)$, adults aged $26-35$ years $(33.7 \%)$ and $\geq 36$ years old $(1.08 \%)$. Education of respondents is mostly still lower at primary school $(83.7 \%)$, and secondary education (16.3\%). Long working respondents mostly between 1-12 months as much as $78.3 \%$ of respondents, $1-3$ years as many as $18.5 \%$ of respondents, $3-5$ years by $2.2 \%$ of respondents, and $>5$ years of $1.1 \%$ of respondents.

In the pretest, the respondents' knowledge about HIV/AIDS is classified into poor $(51.1 \%)$, and average (48.9\%). After given the counseling, those who gain common knowledge is 91 people (98.9\%), and imperfect experience is only one people $(1.1 \%)$. On the pretest, $100 \%$ of respondents have a positive attitude already making the post-test result follows automatically. 63 respondents $(68.5 \%)$ in the pre-test have not had an HIV test and but the number is increased to 88 (95.7) in post-test.

Statistically, there has been a significant difference between pre-test and post-test in the knowledge of HIV / AIDS after counseling. Wilcoxon test obtained p-value $=0.000(<0.05)$ indicating there is a significant difference between pre-test and post-test knowledge of the respondent. Similarly, most of the respondents have a clear attitude between pre-test and post-test after the intervention of counseling. The Wilcoxon test obtained $\mathrm{p}$-value $=0.000$ indicating there is a significant difference between pre-test and posttest respondents' attitudes. Further, most of the respondents have a significant difference between pre-test and post-test in practice after the intervention of counseling. Mc Nemar test obtained $\mathrm{p}$-value $=0.000$ indicating there is a significant difference between pre-test and posttest of respondents in practice.

\section{Discussion}

\section{Univariate analysis}

The prostitutes in Purwokerto, Banyumas Regency most is in the category of the adolescent age range of 15-25 years. At the age of adolescence is a period of productive tending to have a desire to interact with the opposite sex. Prostitutes at this time tend to be more aggressive in their approach to customers. The second order is the respondent in adulthood ranges from 26-35 years. Prostitutes at this time tend to think about the economy because most of their income just from work as a prostitute. According to Prasetyo 
(2015), the age range of 15-20 years highly sells for a prostitute because it is a prostitute only sell beauty. This notion is supported by Efendi (2009) that age effects are used to capture power and the mindset of someone. The age of respondents which is at reproduction age ironically have less knowledge besides there are other factors that affect the level of knowledge of the commercial sex workers, namely the level of low education, information, and experience. Research in Bolivia conducted by Levine (1998) that among sex workers reported that young age is associated with the gonorrhea infection. This indicates the need for prevention and early detection for the prostitutes.

The prostitutes in Purwokerto, Banyumas Regency mostly have primary education. The low education level is one factor to decide to work as a prostitute. They consider that the prostitution is easy to do, does not require higher education and specialized skills. Due to the low levels of education, it will be difficult to look for a job.

The basic concept of knowledge is a learning process, so the higher the school, the more comfortable will be receiving information. Otherwise less education would hinder the development of a person's attitude towards new values introduced. Low literacy can cause irrational thinking patterns and their beliefs to the superstitious, so hard to accept new things (Notoatmodjo, 2007). According to Trilaksono (2007), commercial sex workers reveals that the social stigma makes them difficult reintegrated into society and employment are limited is part of the factors that make the stay work as prostitutes. Another factor is the low education and skill constraints causing them still choose as prostitutes (Rina, 2013).

In this study before being given counseling on HIV/AIDS, most respondents are knowledgeable. But knowledge about HIV / AIDS is still wrong and less precise. There is also a small portion has been answered well although not perfect. The erroneous opinion of the respondents can be caused by lack of comprehension of respondents to the HIV/AIDS information even after getting the information due to a low level of education. According to the concept of Green (2009) that the level of education will affect a person's knowledge. The higher the person's level of education, the higher the person's knowledge of an object.

In this study after being given counseling on HIV / AIDS, there is an increased knowledge of where the majority of the respondents have moderate knowledge that as many as 91 people (98.9\%). Green (2009) state of knowledge can establish absolute confidence that someone is behaving following that belief. Source of knowledge can be obtained from various sources, e.g., print media, electronic media, user guide, health workers, media posters, brochures, friends, and so on.

According to Purwanto (2008), the attitude is the views or feelings that accompanied the tendency to act on the object. So the attitude is always focused on one thing, an object, no attitude without the purpose. Personality can be positive and negative and may also be, in a positive attitude of action is approaching, please, expect a particular object, while the negative attitude there is a tendency to avoid, avoid, hate or do not like a specific object. Before the extension of all respondents as many as 92 people show a positive attitude to take an HIV test, in this case by the opinion of Green ( 2009) that attitudes included in predisposing factors, extraordinarily positive to obey. Attitudes are covered person's response to specific stimuli or objects, which already involves elements of pertinent opinions and emotions (happy-not happy, good-bad, and so on). That attitude is a collection of symptoms in response to a stimulus or object, so that the attitude of the mind, feelings, concerns, and other psychiatric symptoms (Notoatmodjo, 2010). After given counseling, all respondents still have a positive attitude. Although most have the low educational background, it is possible respondents responded matters concerning their health, including information about HIV / AIDS so that the majority 
of respondents have a positive attitude to test for HIV / AIDS.

Before given counseling most respondents did not do HIV/AIDS test as many as 63 people $(68.5 \%)$ and conducted HIV tests as many as 29 people $(31.5 \%)$. Respondents mostly have had the background in lower secondary education who choose not to test for HIV / AIDS. It is possible the lack understanding about HIV / AIDS to see and hear things that are just no sense of hesitation, and need more time to consider a behavior that is important to health. Further, there is a sense of worry or fear when positive HIV / AIDS test results, the prostitutes are not ready to accept the possibility of things that are not desirable, so they choose not to test for HIV / AIDS. After given counseling, the majority of respondents do HIV / AIDS test as many as 88 people $(95.7 \%)$ and who does not perform the analysis as many as four people (4.3\%). Lind (2009) says that the knowledge and understanding of a person affects the perception of the severity of the disease and its vulnerability to HIV / AIDS so think to take some precautions against HIV / AIDS to change the behavior of previously covering the modes of transmission, symptoms and impact of HIV / AIDS and the benefits or constraints in implementing the prevention of one of them by taking an HIV test.

\section{Bivariate analysis}

Results showed that respondents' knowledge before being given counseling on HIV / AIDS was a majority in poor condition $(51.1 \%)$ and after counseling has increased into good ( 98.9\%). Different test respondents' knowledge at the pretest and post-test had a $p$-value $=0.000$, which means there is a difference of commercial sex worker knowledge before and after counseling on HIV / AIDS. Knowledge in this research is the understanding of respondents on HIV / AIDS that includes the modes of transmission, signs, and consequences of infection for patients. According to Notoatmodjo, the knowledge derived from the word "know" and occurs after the person making the senses to something specific object. Most human knowledge is obtained through the eyes and ears. Knowledge covered has six levels, namely 1) know; 2) understand; 3) application; 4) analysis; 5) synthesis and 6) evaluation.

This research is by the theory of Lawrence W Green (2009), states that the knowledge included in the factors that facilitate (predisposing factors)and behavior change affecting attitudes and behavior directly. Knowledge is the basis or foundation of a person to perform specific actions. Thus, by way of counseling edutainment on HIV / AIDS that has been done by the researchers were able to increase knowledge about HIV / AIDS, so that expectations reduce the number of HIV / AIDS on society in general and increase the knowledge of sex workers to test for HIV / AIDS. Similarly, results showed that the respondents' attitudes before being given counseling on HIV / AIDS together with the attitude of the respondent after being given counseling, which gained a total of $100 \%$ of respondents have a positive attitude. The different test respondents' attitudes on the pretest and post-test showed a $p$-value $=0.000$ which means there is a difference in attitude of commercial sex workers before and after counseling on HIV / AIDS.

Attitude is a product of the socialization process in which a person reacts to something with the stimuli received. It is understood that the respondents already know how to behave before and after counseling on HIV / AIDS. They act on the base of knowledge although still in the moderate category and less but already has a positive attitude towards HIV / AIDS test. It will be very supportive to behave more safely in work as commercial sex workers, so it will always pay attention to the health of themselves and customers.

After given counseling, there are 28 respondents who do HIV / AIDS test back, and there is one person not to test HIV / AIDS, there are 60 people who experienced an increase in behavioral analyses of HIV / AIDS, and there are three people which still does not do HIV / AIDS test. 
The different test of respondents in pre-test and post-test for practice denotes a $p$-value $=0.000$, which means there is a difference of commercial sex workers' practices before and after counseling on HIV / AIDS. According to the Lind (2009), conducting HIV / AIDS prevention is knowledge and understanding of a person affecting the perception on the severity of the disease and the vulnerability to contracting HIV / AIDS making someone to take some precautions against HIV / AIDS which includes modes of transmission, symptoms and effect of HIV / AIDS as well as the benefits or obstacles in implementing such prevention.

According Notoatmodjo (2010) behavior can be influenced by internal factors such as age, education, economic status, and the external factors include family support, the support of health, environment, and others. This means that the respondents already know how should act and behave against HIV / AIDS. This is because of their knowledge of HIV / AIDS to form a positive attitude to come to service provided in Health Service Community to get counseling of health and blood tests for examination of HIV / AIDS.

\section{Conclusions}

Before counseling, commercial sex workers in Banyumas Regency, Central Java Province, Indonesia has poor knowledge toward the killing disease of HIV/AIDS. This may be the reason why this regency becomes one of the prevalences of HIV/AIDS the highest. The counseling has been able to increase the awareness of the commercial sex workers in knowledge, attitude, practice and most important is their implementation into regularly examining if they are positively infected by the disease or not by visiting the Health Community nearby. Realizing that the prostitutes are from the low level of education, the health officers must take proactive action in giving enlightenment through counseling on the importance of preventing the disease not only for the prostitutes but also for customers.

\section{Reference}

1. Arikunto, S. 2010. Prosedur Penelitian Suatu Pendekatan Praktik. Jakarta: PT. Rineka Cipta.

2. Dinas Kesehatan Kabupaten Banyumas. 2015. Profil Kesehatan Dinas Kesehatan Banyumas.

3. Effendy N., 2003. Dasar-dasar Keperawatan Kesehatan Masyarakat. Jakarta: EGC.

4. Green, Lawrence W., Judith M. Ottoson, Cesar Garcia, and Robert A. Hiatt. "Diffusion theory and knowledge dissemination, utilization, and integration in public health." Annual review of public health 30 (2009).

5. Lind, Amy. "Governing Intimacy, Struggling for Sexual Rights: Challenging heteronormativity in the global development industry." Development 52, no. 1 (2009): 34-42.

6. Notoatmodjo, S. ,2007. Pendidikan dan Perilaku Kesehatan. Cetakan ke 2. Jakarta: Rineka Cipta.

7. Notoatmodjo, S.. 2010. Ilmu Perilaku Kesehatan. Jakarta: Rineka Cipta.

8. Prasetyo, S. 2015. Latar Belakang dan Karakteristik Pekerja Seks Komersial (PSK) di Kabupaten Batang. Universitas Negeri Semarang.

9. Purwanto, Heri. 2008. Pengantar Perilaku Manusia untuk Keperawatan. Jakarta: EGC.

10. Rina, 2013. Gambaran Karakteristik Tingkat Pengetahuan Pekerja Seks Komersial Terhadap Penularan Penyakit Menular Seksual Di Wilayah Puskesmas Ii Baturaden Kabupaten Banyumas Tahun 2013. (Electronic Thesis or Dissertation). Retrieved from https://repository.shb.ac.id.

11. Trilaksono V. A. 2007. Pengaruh Edukasi tentang HIV/AIDS terhadap Perilaku Pekerja Seks komersial Jalanan Yogyakarta. Universitas Sanata Dharma: Yogyakarta. 